\title{
Protease Catalyzed Production of Spent Hen Meat Hydrolysate Powder for Health Food Applications
}

\author{
Deepak Kumar (D), ${ }^{1}$ Aishwarya Mishra, ${ }^{1}$ Ayon Tarafdar $\mathbb{D}^{2},{ }^{2}$ Abdullah Anwar, \\ Athiya Salagram, ${ }^{1}$ Siraz Alam, ${ }^{1}$ Ashish K. Sahoo, ${ }^{1}$ Raveendran Sindhu $\left(\mathbb{D},{ }^{3}\right.$ \\ and Prarabdh C. Badgujar $\mathbb{D}^{1}$ \\ ${ }^{1}$ Department of Food Science and Technology, National Institute of Food Technology Entrepreneurship and Management, Kundli, \\ Sonipat 131028, Haryana, India \\ ${ }^{2}$ Livestock Production and Management Section, ICAR-Indian Veterinary Research Institute, Izatnagar, Bareilly 243122, \\ Uttar Pradesh, India \\ ${ }^{3}$ Microbial Processes and Technology Division, \\ CSIR-National Institute for Interdisciplinary Science and Technology (CSIR-NIIST), Trivandrum 695019, India
}

Correspondence should be addressed to Prarabdh C. Badgujar; prarabdh.badgujar@gmail.com

Received 2 July 2021; Accepted 29 September 2021; Published 12 October 2021

Academic Editor: Biao Yuan

Copyright ( 92021 Deepak Kumar et al. This is an open access article distributed under the Creative Commons Attribution License, which permits unrestricted use, distribution, and reproduction in any medium, provided the original work is properly cited.

Whole spent hen meat of Indian commercial layer bird (BV-300 breed) was enzymatically hydrolyzed using Flavourzyme ${ }^{\circledR}$ derived from Aspergillus oryzae. Different time, temperature, and $\mathrm{pH}$ combinations generated through response surface methodology (RSM) were tested to find the optimal hydrolysis condition at which maximum antioxidant potential and degree of hydrolysis can be achieved. Hydrolysis for $30 \mathrm{~min}$ at a temperature of $53.9^{\circ} \mathrm{C}$ and $\mathrm{pH}$ of 6.56 was found suitable for achieving high degree of hydrolysis and antioxidant activity. Antioxidant potential at optimized conditions was estimated at $93.26 \% \mathrm{by} \mathrm{DPPH}$ radical scavenging assay and $2.32 \mathrm{mM}$ TEAC by FRAP assay. Amino acid profiling of the hydrolysate correlated very well with SDS-PAGE profiling. SDS-PAGE results confirmed that $30 \mathrm{~min}$ hydrolysis time was enough to produce low molecular weight peptides $(2-5 \mathrm{kDa})$ with high antioxidant potential. Antioxidant rich Indian spent hen meat hydrolysate powder was economically produced using spray drying. Sensory analysis revealed that $10 \%$ hydrolysate powder had satisfactory overall acceptability and has potential to be used in health/functional foods at this concentration. This is the first study wherein optimum hydrolysis conditions for Indian spent hen meat have been reported.

\section{Introduction}

Indian layer industry is growing at the rate of $6-7 \%$ per annum with current population of layer birds estimated at 240 million [1]. As time passes, the hens progress in age and develop cross linkages in their collagen network manifested in less juicy, tougher, and chewier meat [2]. Hens that lose their capacity to lay eggs efficiently are referred to as "spent." Approximately 140 million spent hens are generated annually, taking their laying cycle and moulting into consideration. The increasing number of spent hens is raising a concern for their disposal. Due to the tough texture of spent hen meat, they are often disposed of as landfill, thereby limiting their utilization as a source of food. An efficient alternative for the utilization of spent hen has to be thought of.

Protein hydrolysis employing proteases like Alcalase (endoenzyme) and Flavourzyme (endo- and exoproteases) is emerging as an attractive alternative for food waste utilization. The generated hydrolysates have been shown to possess enhanced nutritional and therapeutic activities including but not limited to antioxidant activity [3, 4], antihypertensive activity [5], hypoglycaemic effect [6], antimicrobial properties [7], and antitumor activity [8]. Functional characteristics of these hydrolysates are due to bioactive peptides formed during hydrolysis of native 
proteins. The extent of bioactivity depends on the source of substrate, nature of enzyme, and hydrolysis conditions. Hydrolysate consists of soluble and insoluble protein fractions among which insoluble portion is generally dried and used for cattle feed. Soluble portion consists of small and medium chain peptides [9]. Pharmaceutical industries incorporate an additional purification step to obtain low molecular weight peptides which are in demand, but the process results in lower yield of hydrolysate and increased production cost. Generally, whole or nonpurified peptides exert higher antioxidant activity than purified peptides [10].

In the current work, we aimed to optimize hydrolysis conditions for the production of spent hen meat hydrolysate with maximum degree of hydrolysis and antioxidant potential. The study also dealt with production of spent hen meat hydrolysate powder with the help of spray drying which can be used for the development of functional food products and nutraceuticals by the processed food industry.

\section{Materials and Methods}

2.1. Materials. Stable free radical: 1,1-diphenyl-2-picrylhydrazyl (DPPH); FRAP reagent: 2,4,6-tri(2-pyridyl)-s-triazine (TPTZ); and Flavourzyme ${ }^{\circledR}$ [a mixture of exo- and endopeptidases (from Aspergillus oryzae), with a declared activity of $\geq 500 \mathrm{U} / \mathrm{g}$ ] were purchased from Sigma-Aldrich (India). All other chemicals used were of high analytical/ACS grade.

2.2. Sample Preparation. Spent hens (BV-300 breed) were procured from the local commercial layer farm and slaughtered by neck cut (bleeding) method as per the regulations prevalent in the country (stunning by electrocuted water) in a nearby butcher shop to obtain boneless meat, which was immediately frozen at $-20^{\circ} \mathrm{C}$. To maintain uniformity in the batch of spent hen meat used, spent hens were procured from the commercial layer farm instead of directly sourcing its meat from the butcher shops. Since no experimental trials were done on the live animals/birds (spent hens), prior approval from Institutional Animal Ethics Committee (IAEC) was not required. Meat was transported to lab in the frozen form which was then converted to smaller meat cuts using frozen block cutter (Sanco, Indonesia) and kept in polyethylene bags at $-20^{\circ} \mathrm{C}$. Prior to experimentation, frozen meat was kept at refrigeration temperature $\left(4^{\circ} \mathrm{C}\right)$ overnight for thawing. Small meat blocks were then minced using a lab scale meat mincer (Sanco, Indonesia). Minced meat was defatted 3 times using hexane ( $1: 10$; meat: hexane). The defatted meat was then mixed with distilled water $(1: 3 \mathrm{w} / \mathrm{w})$ followed by homogenization at $10,000 \mathrm{rpm}$ for a duration of 5 min using a high speed tissue homogenizer (POLYTRON, Kinematica AG, Switzerland).

2.3. Preparation of Hydrolysate. The homogenized meatwater mixture was transferred to a $1 \mathrm{~L}$ bioreactor and heated at a desired temperature. $\mathrm{pH}$ was maintained using $0.1 \mathrm{~N}$ $\mathrm{NaOH}$. The mixture was hydrolyzed using a protease enzyme, Flavourzyme ${ }^{\circledR}$, which was used at an enzyme to substrate ratio of $3 \%(\mathrm{v} / \mathrm{w})$ under appropriate conditions.
Amount of enzyme required for hydrolysis was determined on the basis of crude protein content in the substrate. The experimental levels of independent variables (temperature, $X_{1} ; \mathrm{pH}, X_{2}$; time, $X_{3}$ ) were selected based on preliminary trials, and their effect on the dependent parameters such as degree of hydrolysis $\left(Y_{1}\right)$ and functional properties, as measured by radical scavenging assays, viz., DPPH $\left(Y_{2}\right)$ and FRAP $\left(Y_{3}\right)$, was analyzed. After hydrolysis at different temperatures and $\mathrm{pH}$, the reaction was terminated by heating the mixture at $85^{\circ} \mathrm{C}$ for $20 \mathrm{~min}$ followed by cooling and centrifugation at $6000 \mathrm{~g}$ for $10 \mathrm{~min}$. The resulting supernatant was immediately stored at $4^{\circ} \mathrm{C}$ for further processing.

2.4. Determination of Degree of Hydrolysis. $\mathrm{pH}$-stat method was employed, in which the ratio of number of peptide bonds cleaved to the total number of peptide bonds available for hydrolysis was calculated according to Adler-Nissin [11] using the following equation:

$$
\mathrm{DH}(\%)=\frac{B \times N_{b}}{M_{p} \times \alpha \times h_{\text {total }}} \times 100 .
$$

Here, $B$ is the $\mathrm{NaOH}$ consumed during hydrolysis (in $\mathrm{mL}$ ), $N_{b}$ is the normality of base, $M_{p}$ is the mass of protein (in g), $\alpha$ represents the average degree of dissociation $\left(\alpha-\mathrm{NH}_{2}\right.$ groups), and $h_{\text {total }}$ is the total number of peptide bonds in the protein substrate.

\subsection{Estimation of Antioxidant Potential}

2.5.1. DPPH Radical Scavenging Assay. DPPH radical scavenging activity was estimated according to the procedure reported by Tang et al. [12] with slight modifications. Briefly, liquid hydrolysate $(500 \mu \mathrm{L}, 10 \mathrm{mg} / \mathrm{ml})$ was mixed with $500 \mu \mathrm{L}$ of $0.1 \mathrm{mM}$ ethanolic DPPH. The mixture was vortexed for $5 \mathrm{~min}$ to ensure thorough mixing and left in dark for $30 \mathrm{~min}$. The reaction mixture was then centrifuged at $5,000 \mathrm{~g}$ for $10 \mathrm{~min}$ to remove turbidity. Absorbance of the resulting supernatant was measured at $517 \mathrm{~nm}$ wavelength. Radical scavenging activity was determined using the following equation:

$$
\text { scavenging ability }(\%)=\left(1-\frac{A_{1}-A_{2}}{A_{0}}\right) \times 100 \text {. }
$$

Here, $A_{1}$ is absorbance of $500 \mu \mathrm{L}$ sample $+500 \mu \mathrm{L} \mathrm{DPPH}$ in ethanol; $A_{2}$ is absorbance of $500 \mu \mathrm{L}$ sample $+500 \mu \mathrm{L}$ ethanol; and $A_{0}$ is the absorbance of $500 \mu \mathrm{L} \mathrm{DPPH}$ in ethanol $+500 \mu \mathrm{L}$ distilled water

2.5.2. Ferric Reducing Antioxidant Power (FRAP) Assay. FRAP was assessed according to the method reported by Verma et al. [13] with slight modification. Fresh FRAP reagent $(300 \mathrm{mM}$ acetate buffer $(\mathrm{pH} 3.6)+20 \mathrm{mM}$ ferric chloride $+10 \mathrm{mM}$ TPTZ prepared in $40 \mathrm{mM} \mathrm{HCl}$ ) was prepared in the ratio of $10: 1: 1$ and incubated at $37^{\circ} \mathrm{C}$. From this reagent, $900 \mu \mathrm{L}$ was taken, mixed with $100 \mu \mathrm{L}(25 \mathrm{mg} /$ $\mathrm{ml}$ ) of hydrolysate, and incubated again at $37^{\circ} \mathrm{C}$ for $40 \mathrm{~min}$. 
Absorbance was recorded at $593 \mathrm{~nm}$. Trolox was used for preparing the standard curve $(5-200 \mu \mathrm{m})$.

2.6. Process Optimization. Optimization of hydrolysis conditions was accomplished by response surface methodology (RSM) using face-centered central composite design (FCCCD) and derivative based optimization technique in the Design-Expert software v.10.0.1.

2.7. SDS-PAGE of Optimized Liquid Hydrolysate. Molecular weight distribution of marker and optimized liquid hydrolysate sample were determined by the method given by Laemmli [14]. Samples $(5 \mu \mathrm{L})$ were diluted by Tris$\mathrm{HCl}$ buffer (4\% SDS, $0.2 \mathrm{~mol} / \mathrm{L}$ DTT, $0.125 \mathrm{~mol} / \mathrm{L}$ Tris- $\mathrm{HCl}$, $0.02 \%$ bromophenol blue, $20 \% \mathrm{v} / \mathrm{v}$ glycerol, $\mathrm{pH} 6.8)$. To cleave all noncovalent bonds, samples were boiled for 2 minutes. Gel was casted with 15\% resolving gel and 5\% stacking gel. Electrophoretic separation was done in SE300 miniVE integrated vertical protein electrophoresis and blotting unit assembly (Hoefer, Massachusetts, United States) using power supply of $120 \mathrm{~V}$ in PS300B (Hoefer, Massachusetts, United States). Seven microliters of molecular weight marker of $2-250 \mathrm{kDa}$ (Precision Plus Protein Dual Xtra Standards, Bio-Rad Laboratories Inc., Hercules, CA, USA) range was used.

2.8. Spray Drying of Optimized Hydrolysate. Liquid hydrolysate was mixed with maltodextrin $(5 \mathrm{DE})$ at $10 \%$ concentration. Inlet and outlet temperature were maintained at $160^{\circ} \mathrm{C}$ and $70^{\circ} \mathrm{C}$, respectively, in pilot scale spray drier (SMST, India). Feed was supplied to spray drier using a peristaltic pump maintained at $10 \mathrm{rpm}$. Nozzle pressure was maintained at 10 psi. The spray dried powder was collected in an airtight LDPE Polypack and stored in a desiccator till further analysis.

\subsection{Analysis of Spray Dried Hydrolysate Powder}

2.9.1. Antioxidant Activity. For DPPH assay, sample concentration of $10 \mathrm{mg} / \mathrm{ml}$ was used, and the procedure described in Section 2.5.1 was followed. For FRAP assay, sample concentration used was $25 \mathrm{mg} / \mathrm{ml}$. The same procedure mentioned in Section 2.5.2 was followed.

2.9.2. Amino Acid Profiling. Amino acid composition was estimated by Pico-Tag method as per Kurozawa et al. [9] with slight modification. Protein hydrolysates were digested using $6 \mathrm{~N} \mathrm{HCl} / 0.1 \%$ phenol at $110^{\circ} \mathrm{C}$ for $24 \mathrm{~h}$ and then derivatized with $20 \mu \mathrm{L}$ of ethanol:water:trimethylamine: phenylisothiocyanate solution $(7: 1: 1: 1, \mathrm{v} / \mathrm{v})$. Amino acid composition was then analyzed with HPLC system (NovaPak C18, $4 \mu \mathrm{m}$, Waters, Milford, MA) equipped with reverse phase column.

2.9.3. Essential Amino Acid Score and Protein Efficiency Ratio. Nutritional quality of protein is measured from protein efficiency ratio (PER) and essential amino acid (EA) score. Essential amino acid score was determined by comparing the essential amino acids in hydrolysate with the standard amino acid content requirement for adults [15]. Protein efficiency ratio was calculated by the following equations given by Lee et al. [16]:

$$
\begin{aligned}
& \mathrm{PER}_{7}=0.08084 \times \sum A A_{7}-0.1094, \\
& \mathrm{PER}_{10}=0.0320 \times \sum A A_{10}-0.1539,
\end{aligned}
$$

where $\sum A A_{7}$ is the sum of threonine, valine, methionine, isoleucine, leucine, phenylalanine, and lysine contents (g/ $100 \mathrm{~g}$ protein); $\sum A A_{10}$ is the sum of $\sum A A_{7}$, histidine, arginine, and tryptophan contents $(\mathrm{g} / 100 \mathrm{~g}$ protein).

2.9.4. Sensory Evaluation. Spent hen hydrolysate powder was added to potable drinking water at $\mathrm{H}_{1}(5 \%), \mathrm{H}_{2}(10 \%)$, and $\mathrm{H}_{3}(15 \%)$ to prepare a drink for sensory evaluation. Sensory analysis was done on 9-point hedonic scale, and the quality attributes selected were appearance, aroma, taste, bitterness, and overall acceptability as done by Kumar et al. [17]. Panellists were chosen from the Food Science and Technology and Food Engineering Department of our institute and subjected to training to familiarize them with hydrolysate samples. The three preparations were presented to 15 semi-trained ( 9 male +6 female) panellists in the age group of 20-30 years.

2.10. Statistical Analysis. The number of experiments was 19 following a face-centered central composite design. Experimental data were analyzed and optimized using DesignExpert v.10.0.1 (Stat-Ease Inc.). For proximate studies, all analyses were performed in triplicate. Results of the analyses were reported as mean \pm standard deviation $(n=3)$. Data were analyzed with the help of independent sample $t$-test using SPSS statistical software v.20 at 5\% level of significance $(p<0.05)$.

\section{Results and Discussion}

3.1. Degree of Hydrolysis. Higher degree of hydrolysis is essential for enhancing the solubility of lower molecular weight protein fractions which directly influence the antioxidant potential of the resulting hydrolysate [18]. Experimental values for degree of hydrolysis varied in the range of 15.29-54.23 (Table 1) which was in agreement with that reported by Bhaskar et al. [19] for meat industry waste. Kurozawa et al. [9] reported a maximum degree of hydrolysis of $\sim 38 \%$ for enzymatic hydrolysis of chicken meat with Alcalase ${ }^{\circledR}$, while Zhang and coworkers reported that enzymatic hydrolysis of chicken breast meat with trypsin could produce $\sim 19 \%$ degree of hydrolysis after $8 \mathrm{~h}$ hydrolysis time [20]. On close comparison of literature reports to this study, it is clear that Flavourzyme could show higher performance in yielding lower molecular weight peptides than other proteolytic enzymes for chicken meat hydrolysis. Hydrolysis temperature, time, and $\mathrm{pH}$ had no significant effect $(p>0.05)$ on the degree of hydrolysis when 
TABLE 1: Hydrolysis experiments and corresponding responses.

\begin{tabular}{|c|c|c|c|c|c|c|}
\hline \multirow{2}{*}{ Run } & \multicolumn{3}{|c|}{ Independent variables } & \multicolumn{3}{|c|}{ Response } \\
\hline & Temperature $\left(X_{1}\right)$ & $\mathrm{pH}\left(X_{2}\right)$ & Time $\left(X_{3}\right)$ & $\mathrm{DH}\left(Y_{1}\right)$ & $\mathrm{DPPH}\left(Y_{2}\right)$ & $\operatorname{FRAP}\left(Y_{3}\right)$ \\
\hline 1 & 50 & 7 & 90 & 34.41 & 73.82 & 0.54 \\
\hline 2 & 40 & 5 & 30 & 41.70 & 96.48 & 0.52 \\
\hline 3 & 50 & 6 & 150 & 21.98 & 90.21 & 2.38 \\
\hline 4 & 40 & 7 & 150 & 26.82 & 76.80 & 0.34 \\
\hline 5 & 50 & 6 & 90 & 27.83 & 95.53 & 2.01 \\
\hline 6 & 40 & 7 & 30 & 18.50 & 87.65 & 0.48 \\
\hline 7 & 50 & 6 & 90 & 20.79 & 97.07 & 2.38 \\
\hline 8 & 50 & 5 & 90 & 22.47 & 94.41 & 2.39 \\
\hline 9 & 50 & 6 & 90 & 20.45 & 91.75 & 2.23 \\
\hline 10 & 50 & 6 & 30 & 29.52 & 91.38 & 2.27 \\
\hline 11 & 40 & 5 & 150 & 54.23 & 93.13 & 1.14 \\
\hline 12 & 60 & 6 & 90 & 21.50 & 92.87 & 2.07 \\
\hline 13 & 50 & 6 & 90 & 17.94 & 94.30 & 2.65 \\
\hline 14 & 60 & 7 & 150 & 27.87 & 74.68 & 0.14 \\
\hline 15 & 60 & 5 & 150 & 25.98 & 93.40 & 0.60 \\
\hline 16 & 50 & 6 & 90 & 15.29 & 92.97 & 2.14 \\
\hline 17 & 60 & 5 & 30 & 25.80 & 93.19 & 0.95 \\
\hline 18 & 40 & 6 & 90 & 26.40 & 93.35 & 0.97 \\
\hline 19 & 60 & 7 & 30 & 52.90 & 71.54 & 0.38 \\
\hline
\end{tabular}

$X$ : independent variable, $Y$ : dependent variable.

considered individually (Table 2). However, the interaction between these variables was found significant $(p \leq 0.05)$. For instance, the interaction effect of temperature and $\mathrm{pH}$ had a positive influence on the degree of hydrolysis. Simultaneous increase or decrease in temperature-pH combination generated favorable conditions causing increase in the degree of hydrolysis (Figure 1(a)). Since higher temperature and $\mathrm{pH}$ conditions could facilitate breakdown of the tightly bound chicken meat fibres, more active sites for the enzyme are available. Lower hydrolysis temperature and $\mathrm{pH}$ allow for optimum enzymatic activity which could contribute to significant increase in degree of hydrolysis (Figure 1(a)). The interaction effect of $\mathrm{pH}$ and hydrolysis time also affected degree of hydrolysis significantly $(p \leq 0.05)$ (Figure $1(b)$ ).

\subsection{Antioxidant Potential}

3.2.1. DPPH Radical Scavenging Activity. Hydrolysis temperature and $\mathrm{pH}$ significantly affected DPPH free radical scavenging activity $(p \leq 0.05)$. It was found that free radical scavenging activity (FRSA) ranged from $71.54 \%$ to $97.07 \%$. Model plots (Figures 1(d)-1(f)) revealed a relatively constant FRSA with increase in $\mathrm{pH}$ up to 5.5 followed by a gradual decrease in FRSA which continued to a $\mathrm{pH}$ of 7.0. Wang et al. [21] also reported a decrease in DPPH scavenging potential for duck meat protein hydrolysates beyond a $\mathrm{pH}$ of 5.5. During hydrolysis, chicken meat protein breaks down into lower molecular weight peptides that have functional attributes and contribute to antioxidant potential. When $\mathrm{pH}$ of the medium surrounding these peptides increases, they undergo structural modification and thereby lose their capability to scavenge free radicals. Negative model coefficient for $\mathrm{pH}$ (Table 2) confirmed the hypothesis that increase in $\mathrm{pH}$ would result in reduced FRSA. Increase in temperature also showed a similar decrease in FRSA
TABLE 2: Second order model coefficients obtained after regression analysis between experimental variables and responses.

\begin{tabular}{lcccccc}
\hline $\begin{array}{l}\text { Model } \\
\text { coefficient }\end{array}$ & Coeff. & $\begin{array}{c}p \\
\text { value }\end{array}$ & Coeff. & $\begin{array}{c}p \\
\text { value }\end{array}$ & Coeff. & $\begin{array}{c}p \\
\text { value }\end{array}$ \\
\hline $\begin{array}{lcccccc}\text { Intercept } \\
\text { A- hydrolysis }\end{array}$ & 93.260 & $\leq 0.001$ & 2.320 & $\leq 0.001$ & 20.950 & $\leq 0.001$ \\
temp & -2.180 & $\leq 0.030$ & 0.068 & $\leq 0.630$ & -1.360 & $\leq 0.460$ \\
B- hydrolysis & -8.610 & $\leq 0.001$ & -0.371 & $\leq 0.020$ & -0.968 & $\leq 0.600$ \\
pH & & & & & & \\
C- hydrolysis & -1.200 & $\leq 0.190$ & -0.000 & $\leq 0.990$ & -1.150 & $\leq 0.530$ \\
time & -1.900 & $\leq 0.070$ & -0.023 & $\leq 0.880$ & 9.950 & $\leq 0.001$ \\
AB & 2.190 & $\leq 0.040$ & -0.133 & $\leq 0.400$ & -5.710 & $\leq 0.010$ \\
AC & -0.571 & $\leq 0.560$ & -0.083 & $\leq 0.590$ & -3.680 & $\leq 0.090$ \\
BC & 1.190 & $\leq 0.480$ & -0.829 & $\leq 0.010$ & 2.380 & $\leq 0.500$ \\
$A^{2}$ & -7.800 & $\leq 0.001$ & -0.882 & $\leq 0.001$ & 6.870 & $\leq 0.070$ \\
$B^{2}$ & -1.120 & $\leq 0.500$ & -0.021 & $\leq 0.930$ & 4.180 & $\leq 0.250$ \\
$C^{2}$ & 0.972 & 0.939 & 0.930 \\
$r$ & 0.946 & 0.883 & 0.864 \\
$R^{2}$ & 2.700 & 0.433 & 5.640 \\
SD & & & & & & \\
\hline
\end{tabular}

$r$ : correlation coefficient, $R^{2}$ : regression coefficient, SD: standard deviation, Coeff.: coefficient.

(Figures 1(d)-1(f)). It was observed that increasing the temperature from $40^{\circ} \mathrm{C}$ to $60^{\circ} \mathrm{C}$ resulted in $5-25 \%$ decrease in FRSA (Table 1). Our finding is in parallel with those of other researchers who have given a plausible reason that, at elevated temperatures, denaturation of Flavourzyme could lead to lower degree of hydrolysis resulting in decreased formation of bioactive peptides, consequently reducing the FRSA [22]. Hydrolysis time was found to insignificantly affect the DPPH radical scavenging activity $(p>0.05)$ which shows that lower time of hydrolysis can be selected to reduce the energy consumed during the process without 


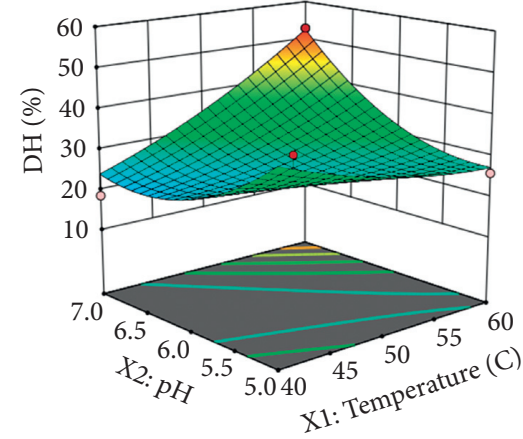

(a)

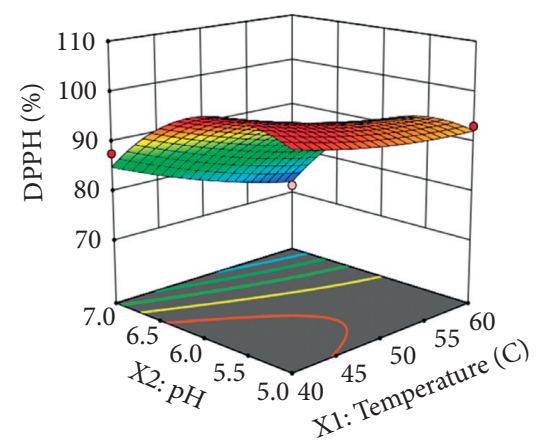

(d)

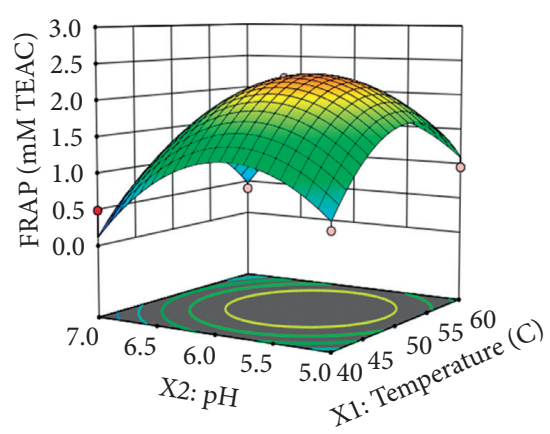

(g)

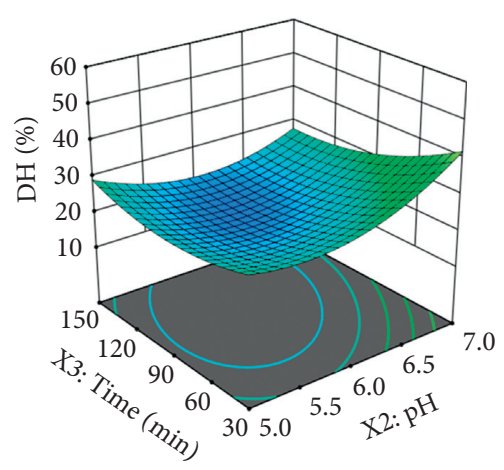

(b)

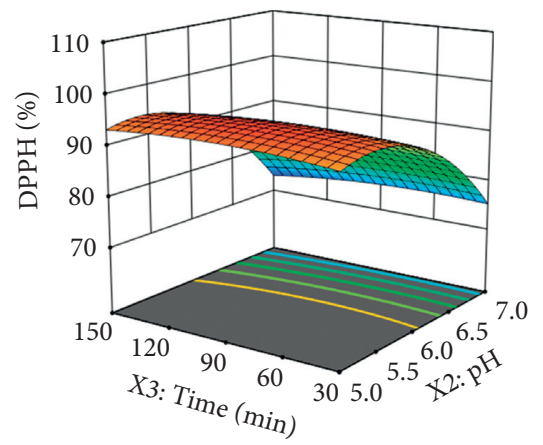

(e)

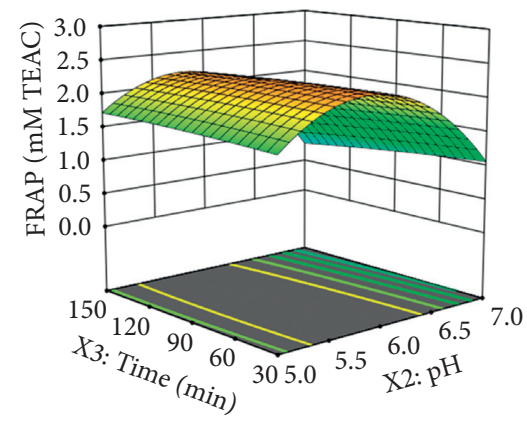

(h)

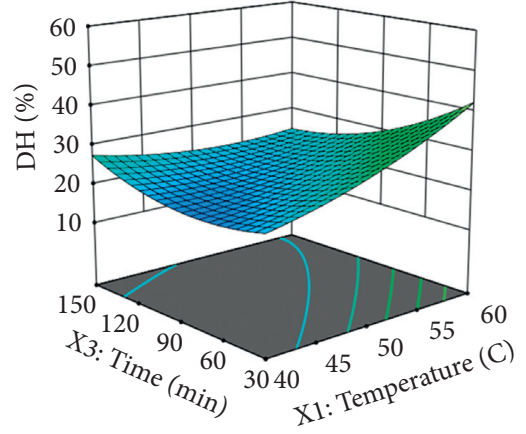

(c)

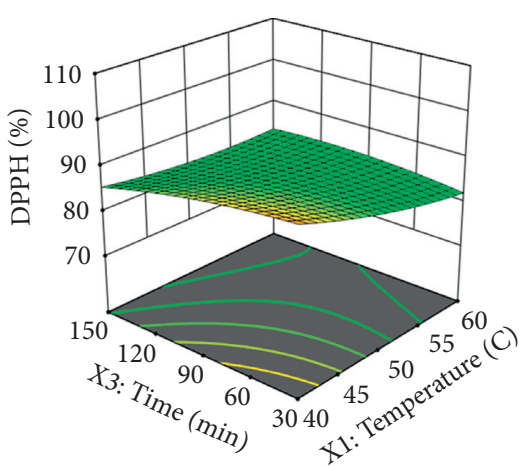

(f)

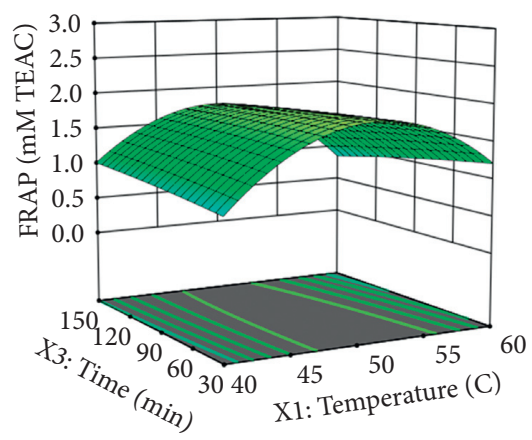

(i)

FIgURE 1: Response surface plots for degree of hydrolysis (a-c), DPPH scavenging activity (d-f), and FRAP (g-i) for spent hen meat hydrolysates.

compromising the antioxidant potential of the hydrolysate. Literature suggests that antioxidant potential of hydrolysates varies significantly up to $1 \mathrm{~h}$ of hydrolysis [23]. On the contrary, the results of this study show no distinct change in FRSA, perhaps due to a change in substrate under consideration.

3.2.2. FRAP. Temperature and $\mathrm{pH}$ significantly affected the ferric reducing antioxidant power $(p \leq 0.05)$. Increasing $\mathrm{pH}$ up to 6.0 and temperature up to $50^{\circ} \mathrm{C}$ enhanced FRAP (Figures $1(\mathrm{~g})-1(\mathrm{i})$ ). At higher $\mathrm{pH}$ and temperatures, a steep decrease in FRAP was observed possibly due to enzyme denaturation. Wang and Shahidi [24] also reported a similar trend in reducing power of Turkey meat protein hydrolysates. Decrease in FRAP with increased $\mathrm{pH}$ and temperature was consistent with negative model coefficient for the variables (Table 2). In addition to a quadratic coefficient, the linear coefficient of $\mathrm{pH}$ was also found to be significant. This indicated that decrease in FRAP with $\mathrm{pH}$ was more gradual as compared to its decrease with temperature which only had a significant quadratic coefficient. A quadratic nature of the results also indicate that the size of peptides can influence the rate of hydrolysis since smaller molecular weight peptides can diffuse faster in the medium which can be only generated up to a specific hydrolysis condition. Hydrolysis time affected FRAP insignificantly $(p>0.05)$. Estimated effects of variables in FRAP were similar to those observed for FRSA, which indirectly shows a strong positive correlation between the former and the latter. Similar effect of hydrolysis time on FRAP and DPPH scavenging activity also proves that antioxidants will not be greatly influenced if hydrolysis times 
are reduced generating a possibility of process cost reduction by reduction in operating time.

3.3. Process Optimization. Optimization of hydrolysis processing conditions was carried out using the regression models developed for the dependent variables (Table 2). The purpose of optimization algorithm was to search for processing conditions that would offer maximum degree of hydrolysis and antioxidant potential with fastest hydrolysis time. The algorithm generated 37 solutions, of which the solution with the highest desirability was selected. Optimum temperature for hydrolysis was observed as $53.9^{\circ} \mathrm{C}$ with a hydrolysis time of $30 \mathrm{~min}$ at $\mathrm{pH}$ 6.56. Extended experiments were conducted at the optimized hydrolysis conditions, and the resulting hydrolysates were subsequently dried to form a powder.

3.4. SDS-PAGE of Optimized Liquid Hydrolysate. SDS-PAGE profiling of optimized liquid hydrolysate was done to analyze the molecular weight distribution of peptides in the hydrolysate and to confirm the extent of hydrolysis which has taken place. When SDS-PAGE profile of the sample was compared with marker, it showed that enzymatic treatment was effective in breaking large peptide chains into very smaller peptides of molecular weight of $2-5 \mathrm{kDa}$ (Figure 2). Peptide bands in the molecular weight region of $75 \mathrm{kDa}, 55 \mathrm{kDa}, 50 \mathrm{kDa}$, and $25 \mathrm{kDa}$ were also observed. After extensive literature survey, we could not find any report of spent hen meat/chicken meat hydrolysis using Flavourzyme. This is the first report of molecular weight profiling of spent hen meat hydrolysate by SDS-PAGE technique. Since Flavourzyme is both endo- and exopeptidase, it generated a very good number of small peptides. However, in parallel to our findings, Nchienzia et al. [25] reported low molecular weight peptides after $30 \mathrm{~min}$ hydrolysis of poultry meal with $20.95 \%$ degree of hydrolysis and resultantly good antioxidant activity.

\subsection{Analysis of Spray Dried Hydrolysate Powder}

3.5.1. Antioxidant Activity. Spray dried hydrolysate powder showed significantly higher $(p \leq 0.05)$ DPPH value as compared to liquid hydrolysate. Similar results were obtained for FRAP assay. Spray dried hydrolysate powder showed $\mathrm{Fe}^{3+}$ reducing power of $2.42 \pm 0.21 \mathrm{mM}$ TEAC over $1.71 \pm 0.55 \mathrm{mM}$ TEAC for liquid hydrolysate. Since spray drying removes most of the moisture present in the liquid feed, the concentration of low and medium molecular weight peptides increases. This in turn increases the free radical scavenging activity exhibited by the low molecular weight peptides present in the powdered hydrolysate [26]. Results of amino acid profiling also prove that high amount of histidine $(3.59 \mathrm{~g} / 100 \mathrm{~g})$ present in the hydrolysate powder could be responsible for higher antioxidant activity obtained in this study probably due to decomposition of imidazole moiety of histidine as suggested by Wang et al. [21]. Higher antioxidant activity of the hydrolysate powder than its liquid state translates well into its potential utilization in the functional foods and nutraceuticals.

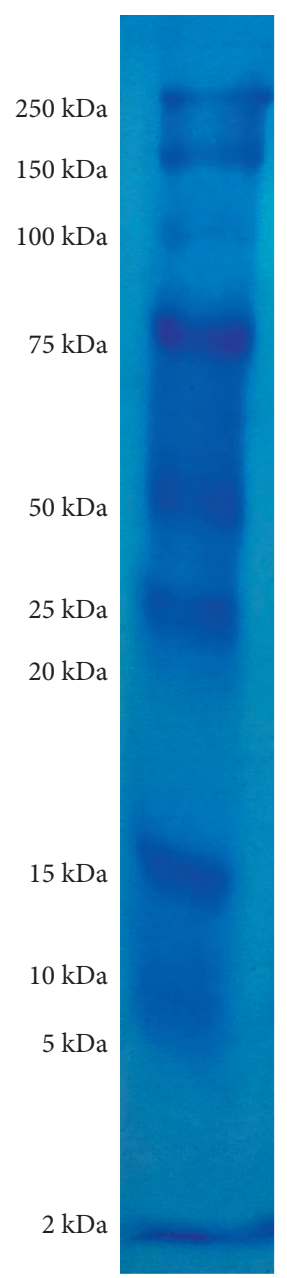

(a)

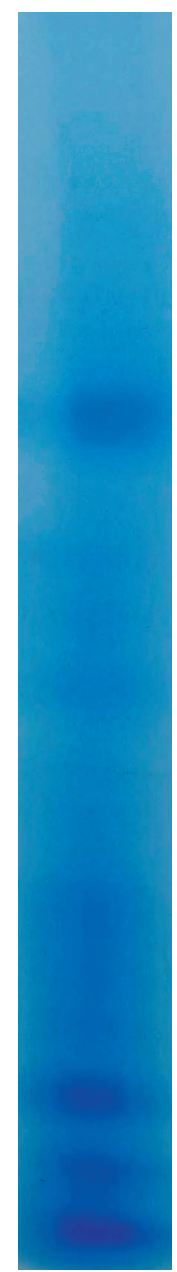

(b)
FIGURE 2: SDS-PAGE profile of (a) molecular weight marker and (b) optimized liquid hydrolysate.

3.5.2. Amino Acid Profiling. Amino acid composition of spray dried spent hen meat hydrolysate powder was analyzed to observe possible effect of amino acid profiling on its antioxidant potential. Results of amino acid profiling are presented in Table 3. Amount of amino acids such as glutamic acid, histidine, lysine, and tryptophan was found to be comparatively higher in the developed hydrolysate powder. It has been reported that histidine shows strong antioxidant activity owing to decomposition of imidazole ring [21, 27]; however, amino acids such as tryptophan, histidine, tyrosine, lysine, and methionine are also known to exhibit good antioxidant potential [28]. Essential amino acid (EA) accounts for $59.56 \%$ of all the amino acids shown in Table 3 . Thus, results of amino acid profiling also hold significance with respect to the nutritional quality of the hydrolysate powder.

3.5.3. Essential Amino Acid Score and Protein Efficiency Ratio. EA score and PER are two criteria to judge the nutritional quality of protein hydrolysate. The higher the PER and EA score are, the better the nutritional quality will 
TABle 3: Amino acid composition (g/100 g protein) of spent hen meat and spray dried spent hen meat hydrolysate powder.

\begin{tabular}{|c|c|c|c|c|c|}
\hline Amino acid & Spent hen meat & SD-SHMH powder & FAO/WHO $(2002)^{*}$ & $\begin{array}{l}\text { EA score (spent hen } \\
\text { meat) }\end{array}$ & $\begin{array}{c}\text { EA score (spray dried hydrolysate } \\
\text { powder) }\end{array}$ \\
\hline \multicolumn{6}{|l|}{ Nonessential } \\
\hline Alanine & 5.41 & 4.12 & - & - & - \\
\hline Arginine & 5.37 & 6.96 & - & - & - \\
\hline Aspartic acid & 7.15 & 5.78 & - & - & - \\
\hline Cystine & 1.19 & 0.14 & - & - & - \\
\hline Glutamic acid & 13.81 & 11.89 & - & - & - \\
\hline Glycine & 3.51 & 3.44 & - & - & - \\
\hline Proline & 2.33 & 2.02 & - & - & - \\
\hline Serine & 3.19 & 2.06 & - & - & - \\
\hline Tyrosine & 2.94 & 2.77 & - & - & - \\
\hline \multicolumn{6}{|l|}{ Essential } \\
\hline Histidine & 3.67 & 3.59 & 1.5 & 2.45 & 2.39 \\
\hline Isoleucine & 7.94 & 7.81 & 3 & 2.65 & 2.60 \\
\hline Leucine & 7.56 & 6.64 & 5.9 & 1.28 & 1.13 \\
\hline Lysine & 7.55 & 7.15 & 4.5 & 1.68 & 1.59 \\
\hline Methionine & 8.25 & 6.19 & $2.2^{* *}$ & 3.75 & 2.81 \\
\hline Phenylalanine & 3.35 & 3.22 & $3^{* * *}$ & 1.12 & 1.07 \\
\hline Threonine & 4.15 & 6.56 & 2.3 & 1.80 & 2.85 \\
\hline Tryptophan & 9.32 & 11.29 & 0.6 & 15.53 & 18.15 \\
\hline Valine & 5.41 & 5.27 & 3.9 & 1.39 & 1.35 \\
\hline
\end{tabular}

be. Table 3 shows that the EA scores of all the essential amino acids of spray dried spent hen meat hydrolysate powder were fairly good $(E A>1)$, which means all the essential amino acids are present in adequate amounts, while tryptophan was found to be present in excess (EA score $>>1$ ). EA values were calculated by considering the adult requirement. EA values of more than 1 signify that protein contains specific essential amino acid in excess of the requirement of adult. This excess amino acid can serve to complement any food limiting in that specific amino acid.

$\mathrm{PER}_{7}$ and $\mathrm{PER}_{10}$ were calculated by considering the 7 and 10 amino acids, respectively. $\mathrm{PER}_{7}$ was found to be higher for spent hen meat (3.46) than that of spray dried hydrolysate powder (3.35), while $\mathrm{PER}_{10}$ of spray dried hydrolysate powder was higher (3.93) as compared to the spent hen meat (3.80) due to the inflated value of tryptophan. $\mathrm{PER}_{10}$ of spray dried developed hydrolysate was found to be higher than the chicken protein hydrolysate (3.49) [9] and shrimp protein hydrolysate (2.99) [29]. The high PER and EA values of spray dried hydrolysate powder render it perfect candidate for use in protein supplement or for functional food development $[30,31]$.

3.5.4. Sensory Evaluation. For sensory evaluation, three different formulations were prepared in water using spray dried hydrolysate powder. Samples $\mathrm{H}_{1}$ and $\mathrm{H}_{2}$ were found satisfactory with $\mathrm{H}_{2}$ being the highest acceptable concentration when compared among all three samples. Overall acceptability was reduced drastically from $\mathrm{H}_{2}$ to $\mathrm{H}_{3}$ scoring 6.9 and 3.7 on hedonic scale, respectively (Figure 3). Taste attribute of $\mathrm{H}_{3}$ was "disliked very much" when compared with $\mathrm{H}_{2}$ which was "liked slightly." Bitterness of all three samples was acceptable as hydrolysis was done only for 30 min (optimized time). Bitter peptides in hydrolysates are

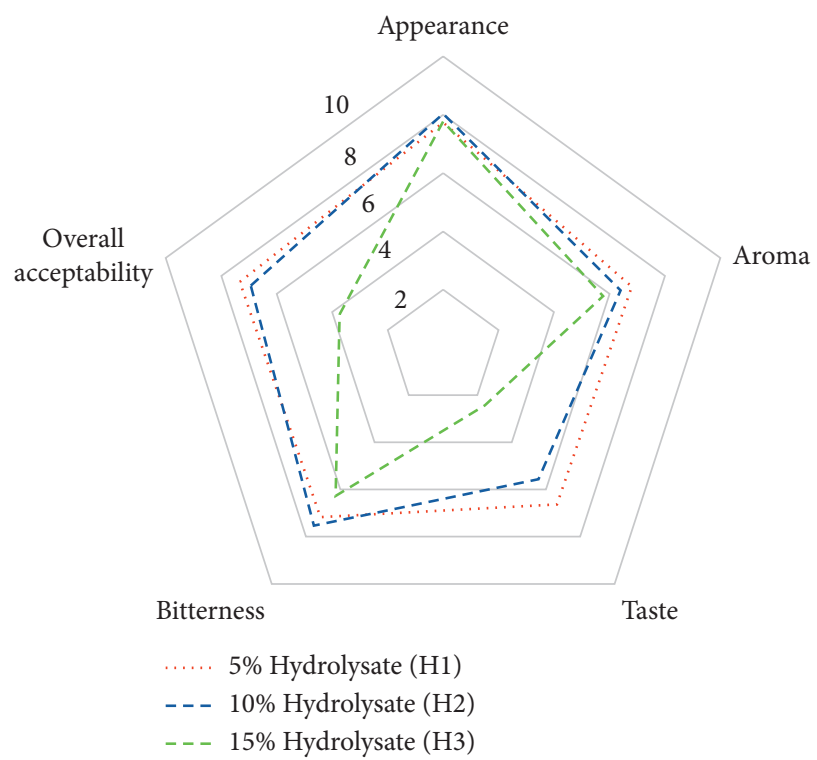

Figure 3: Sensory analysis of spent hen meat hydrolysate powder formulations.

known to develop only after extensive hydrolysis of 6-24h [27]. Based on sensory evaluation, it was evident that $10 \%$ hydrolysate concentration $\left(\mathrm{H}_{2}\right)$ can be suitably used for the development of nutraceuticals and functional foods which can be easily and economically disseminated in the form spray dried powders [32]. Again, we are the first to report sensory analysis of spent hen meat hydrolysate powder (or that of chicken meat hydrolysate powder, for that matter) and its acceptable percentage to be added/mixed in the functional foods. Furthermore, the maltodextrin (its type, 
i.e., $\% \mathrm{DE}$ ) and its concentration to be used in spray drying of spent hen meat hydrolysate will help food industry to use the same at commercial scale. The bitterness of such powders has been reported to be lower when maltodextrin is used as a carrier agent in spray drying of whey protein hydrolysate and casein protein hydrolysate [33].

\section{Conclusions}

Temperature of $53.9^{\circ} \mathrm{C}$ with 30 min hydrolysis time and $\mathrm{pH}$ of 6.56 was found optimum for spent hen meat protein hydrolysis using Flavourzyme ${ }^{\circledR}$. SDS-PAGE profile of spent hen meat protein hydrolysate showed good resolution of low molecular weight peptides at optimized conditions which were associated with antioxidant potential. Spray dried spent hen meat hydrolysate powder exhibited good functional properties when compared with its liquid counterpart. Amino acid profiling substantiated findings of high antioxidant activity shown by hydrolysate powder as some of the amino acids such as histidine, lysine, and methionine were present in good quantity. Sensory analysis of spent hen meat hydrolysate powder revealed that it can be suitably used in egg/chicken-based protein supplements and health foods. The results of this study hold significance to the nutraceutical and functional food industry for the potential exploitation of the developed hydrolysate powder.

\section{Data Availability}

All the data pertaining to this study have been provided within the manuscript.

\section{Conflicts of Interest}

The authors declare that there are no conflicts of interest.

\section{Authors' Contributions}

Deepak Kumar and Aishwarya Mohan contributed equally to this work.

\section{Acknowledgments}

The authors are grateful to the Vice Chancellor, National Institute of Food Technology Entrepreneurship and Management (NIFTEM), Kundli, Sonipat, for providing necessary facilities and funds to carry out this research work. The first author, Deepak Kumar, thanks UGC (India) for providing fellowship vide NTA reference no. 190510017474.

\section{References}

[1] T. Kotaiah, "Poultry production in India-the current scenario," Food and Beverage News, http://www.fnbnews.com/ Poultry/poultry-production-in-india--the-current-scenario38620, 2016.

[2] E. N. Frankel and A. J. Baily, "Recent advances in the chemistry of meat," Food Chemistry, vol. 15, no. 4, pp. 315-316, 1984.

[3] S. Prajapati, S. Koirala, and A. K. Anal, "Bioutilization of chicken feather wastes by newly isolated keratinolytic bacteria into protein hydrolysates with improved functionalities," Applied Biochemistry and Biotechnology, vol. 193, pp. 24972515, 2021.

[4] J. O. Onuh, A. T. Girgih, R. E. Aluko, and M. Aliani, "In vitro antioxidant properties of chicken skin enzymatic protein hydrolysates and membrane fractions," Food Chemistry, vol. 150, pp. 366-373, 2014.

[5] T. A. Aderinola, T. N. Fagbemi, V. N. Enujiugha, A. M. Alashi, and R. E. Aluko, "In vitro antihypertensive and antioxidative properties of alcalase-derived Moringa oleifera seed globulin hydrolysate and its membrane fractions," Journal of Food Processing and Preservation, vol. 43, no. 2, Article ID e13862, 2019.

[6] R. Nasri, O. Abdelhedi, I. Jemil et al., "Ameliorating effects of goby fish protein hydrolysates on high-fat-high-fructose dietinduced hyperglycemia, oxidative stress and deterioration of kidney function in rats," Chemico-Biological Interactions, vol. 242, pp. 71-80, 2015.

[7] J. Salampessy, M. Phillips, S. Seneweera, and K. Kailasapathy, "Release of antimicrobial peptides through bromelain hydrolysis of leatherjacket (meuchenia sp.) insoluble proteins," Food Chemistry, vol. 120, no. 2, pp. 556-560, 2010.

[8] Z. Xue, J. Gao, Z. Zhang, W. Yu, H. Wang, and X. Kou, "Antihyperlipidemic and antitumor effects of chickpea albumin hydrolysate," Plant Foods for Human Nutrition, vol. 67, no. 4, pp. 393-400, 2012.

[9] L. E. Kurozawa, K. J. Park, and M. D. Hubinger, "Optimization of the enzymatic hydrolysis of chicken meat using response surface methodology," Journal of Food Science, vol. 73, no. 5, pp. C405-C412, 2008.

[10] B. H. Sarmadi and A. Ismail, "Antioxidative peptides from food proteins: a review,” Peptides, vol. 31, no. 10, pp. 1949-1956, 2010.

[11] J. Adler-Nissen, Enzymic Hydrolysis of Food Proteins, Elsevier Applied Science Publishers, London, UK, 1986.

[12] W. L. Tang, M. Zhang, B. Adhikari, and A. S. Mujumdar, "Effects of preparation and drying methods on the antioxidant activity of enzymatically hydrolyzed porcine placenta hydrolysates," Drying Technology, vol. 31, no. 13-14, pp. 1600-1610, 2013.

[13] A. K. Verma, M. K. Chatli, P. Kumar, and N. Mehta, “Antioxidant and antimicrobial activity of protein hydrolysate extracted from porcine liver," The Indian Journal of Animal Sciences, vol. 87, no. 6, pp. 711-717, 2017.

[14] U. K. Laemmli, "Cleavage of structural proteins during the assembly of the head of bacteriophage T4," Nature, vol. 227, no. 5259, pp. 680-685, 1970.

[15] [FAO/WHO] Food and Agriculture Organization/World Health Organization, "Evaluation of protein quality. joint FAO/WHO report," FAO Food Nutrition, Rome, 2002.

[16] Y. B. Lee, J. G. Elliott, D. A. Rickansrud, and E. Y. C. Hagberg, "Predicting protein efficiency ratio by the chemical determination of connective tissue content in meat," Journal of Food Science, vol. 43, no. 5, pp. 1359-1362, 1978.

[17] Y. Kumar, A. Tarafdar, D. Kumar, and P. C. Badgujar, "Effect of Indian brown seaweed Sargassum wightii as a functional ingredient on the phytochemical content and antioxidant activity of coffee beverage," Journal of Food Science and Technology, vol. 56, no. 10, pp. 4516-4525, 2019.

[18] S. Dong, M. Zeng, D. Wang, Z. Liu, Y. Zhao, and H. Yang, "Antioxidant and biochemical properties of protein hydrolysates prepared from silver carp (Hypophthalmichthys molitrix)," Food Chemistry, vol. 107, no. 4, pp. 1485-1493, 2008. 
[19] N. Bhaskar, V. K. Modi, K. Govindaraju, C. Radha, and R. G. Lalitha, "Utilization of meat industry by products: protein hydrolysate from sheep visceral mass," Bioresource Technology, vol. 98, no. 2, pp. 388-394, 2007.

[20] Y. Zhang, Y. Wang, F. Jiang, and H. Jin, "Sensory characteristics of maillard reaction products from chicken protein hydrolysates with different degrees of hydrolysis," CyTA-Journal of Food, vol. 17, no. 1, pp. 221-227, 2019.

[21] J. Wang, M. Zhao, Q. Zhao, and Y. Jiang, "Antioxidant properties of papain hydrolysates of wheat gluten in different oxidation systems," Food Chemistry, vol. 101, no. 4, pp. 1658-1663, 2007.

[22] J. Roslan, M. S. Kamal, M. K. Yunos, and N. Abdullah, "Optimization of enzymatic hydrolysis of tilapia (Oreochromis niloticus) byproduct using response surface methodology," International Food Research Journal, vol. 22, no. 3, p. 1117, 2015.

[23] D. Wang, M. Zhang, Y. Zou, Z. Sun, and W. Xu, "Optimization of flavourzyme hydrolysis condition for the preparation of antioxidant peptides from duck meat using response surface methodology," The Journal of Poultry Science, vol. 55, pp. 217-223, Article ID 0160155, 2018.

[24] D. Wang and F. Shahidi, "Protein hydrolysate from Turkey meat and optimization of its antioxidant potential by response surface methodology," Poultry Science, vol. 97, no. 5, pp. 1824-1831, 2018.

[25] H. A. Nchienzia, R. O. Morawicki, and V. P. Gadang, "Enzymatic hydrolysis of poultry meal with endo-and exopeptidases," Poultry Science, vol. 89, no. 10, pp. 2273-2280, 2010.

[26] C. Chen, Y. J. Chi, and W. Xu, "Comparisons on the functional properties and antioxidant activity of spray-dried and freeze-dried egg white protein hydrolysate," Food and Bioprocess Technology, vol. 5, no. 6, pp. 2342-2352, 2012.

[27] B. Y. Liu, K. X. Zhu, W. Peng, X. N. Guo, and H. M. Zhou, "Effect of sequential hydrolysis with endo-and exo-peptidase on bitterness properties of wheat gluten hydrolysates," RSC Advances, vol. 6, no. 33, pp. 27659-27668, 2016.

[28] L. You, M. Zhao, C. Cui, H. Zhao, and B. Yang, "Effect of degree of hydrolysis on the antioxidant activity of loach (Misgurnus anguillicaudatus) protein hydrolysates," Innovative Food Science \& Emerging Technologies, vol. 10, no. 2, pp. 235-240, 2009.

[29] S. S. Dey and K. C. Dora, "Optimization of the production of shrimp waste protein hydrolysate using microbial proteases adopting response surface methodology," Journal of Food Science and Technology, vol. 51, no. 1, pp. 16-24, 2014.

[30] D. Kumar, A. Jyoti, A. Tarafdar, A. Kumar, and P. C. Badgujar, "Comparative functional and spectroscopic analysis of spent hen meat hydrolysate by individual and combined treatment of microbial proteases," Preparative Biochemistry \& Biotechnology, vol. 51, no. 6, pp. 618-627, 2021.

[31] D. Kumar, A. Mishra, A. Tarafdar et al., "In vitro bioaccessibility and characterisation of spent hen meat hydrolysate powder prepared by spray and freeze-drying techniques," Process Biochemistry, vol. 105, pp. 128-136, 2021.

[32] P. Unnikrishnan, B. Puthenveetil Kizhakkethil, M. Anant Jadhav et al., "Protein hydrolysate from yellowfin tuna red meat as fortifying and stabilizing agent in mayonnaise," Journal of Food Science and Technology, vol. 57, no. 2, pp. 413-425, 2020.

[33] P. S. Rao, R. K. Bajaj, B. Mann, S. Arora, and S. K. Tomar, "Encapsulation of antioxidant peptide enriched casein hydrolysate using maltodextrin-gum Arabic blend," Journal of Food Science and Technology, vol. 53, no. 10, pp. 3834-3843, 2016. 